\title{
Innovation in the Experience Sector
}

Sundbo, Jon; Sørensen, Flemming; Fuglsang, Lars

\section{Publication date:}

2010

\section{Document Version}

Publisher's PDF, also known as Version of record

Citation for published version (APA):

Sundbo, J., Sørensen, F., \& Fuglsang, L. (2010). Innovation in the Experience Sector. Roskilde Universitet. Forskningsrapport / Center for Servicestudier, Roskilde Universitetscenter Vol. 2010 No. 7

\section{General rights}

Copyright and moral rights for the publications made accessible in the public portal are retained by the authors and/or other copyright owners and it is a condition of accessing publications that users recognise and abide by the legal requirements associated with these rights.

- Users may download and print one copy of any publication from the public portal for the purpose of private study or research. - You may not further distribute the material or use it for any profit-making activity or commercial gain.

- You may freely distribute the URL identifying the publication in the public portal.

\section{Take down policy}

If you believe that this document breaches copyright please contact rucforsk@kb.dk providing details, and we will remove access to the work immediately and investigate your claim. 


\section{RESEARCH REPORT}

\section{Innovation in the Experience Sector}

Jon Sundbo

Flemming Sørensen

Lars Fuglsang

CSS

CENTRE OF SERVICE STUDIES 


\section{ROSKILDE UNIVERSITY}

\section{Report no. 10:7}

Print: Roskilde universitetscenters trykkeri

ISSN 1600-1966

\section{Published by}

Centre of Service Studies

Roskilde University

Building 44.3, PO Box 260

DK-4000 Roskilde 


\title{
Innovation in the experience sector
}

\author{
Abstract: \\ This paper presents the first general investigation of innovation in the \\ experience sector based on a survey. The results are compared to innovation \\ activities in service and manufacturing sectors. The investigation shows that \\ innovation is a common phenomenon in the experience sector. The share of \\ firms that innovate is significantly above other sectors'. The characteristics of \\ the experience innovations and innovative firms are similar to those found in \\ services (and to a large degree in manufacturing).
}

Keywords: Innovation, experience

\section{Introduction}

Pine and Gilmore's book The Experience Economy was published in 1999 and is generally regarded as the source of a new paradigm or discourse within business economics. It proclaimed the existence of a new sector with its own logic - the experience sector. We might suppose that innovation in this sector is as important as in any other. However, given the newness of the topic no research has been undertaken to confirm this. Thus this article presents the first general investigation of innovation in the experience sector based on a survey.

The survey was carried out in Denmark in 2007. The survey can in some aspects be compared to the European CIS surveys (Eurostat 2004). Several questions from the CIS survey were included in the Danish survey. 
Experience can be defined as a mental journey, which leaves an immaterial impression - in the form of knowledge or a mental state (cf. Sundbo 2009a). Different experiences can be distinguished such as amusing experiences or educating experiences. An experience can be a facet of many kinds of goods and services (for example design of cars and furniture and authors reading poems in the coffee shop in a bank). Experience can also be defined as a particular economic sector composed of firms that have the production of experiences as their core activity. This sector would include enterprises within, for example, culture, sport, tourism, ICT-based experiences such as computer games and cartoons sent to mobile phones, and town festivals. It includes what have been called creative industries (Caves 2000), but is broader than that.

\section{Aim of the study}

The survey on which this paper is based investigates innovation in the primary experience sector, i.e. firms that have the production of experiences as their core activity. These firms have never been included in innovation surveys and we therefore do not know anything about their innovation activities. There exist no authorised and generally accepted definition of the primary experience sector. We have applied a definition that has been used in an investigation of the Danish experience sector made by the Ministry of Industry (Erhvervs- og byggestyrelsen 2008). Thereby we can compare some results with that investigation. The primary experience sector as defined here includes, for example, restaurants, travel agencies, publishers of discs and CDs, cinemas, theatres, amusement parks and museums. The primary experience sector has earlier been considered part of the service sector, however, Pine and Gilmore's (1999) view has defined it as a sector of its own.

The research questions raised here are: Is innovation in experiences different from that in (other) services, and can innovation in experience be measured in 
the same way as has been done in (other) services? It is important to answer these questions if we want to understand experience production in a business perspective and include experience industries in innovation policies. These questions are also relevant if we want to develop theories about innovation in experience industries and firms.

\section{Theory}

Before we answer these two questions empirically, we will discuss, briefly, the first question theoretically, thus providing a preliminary framework for understanding the character of experience innovations, and an evaluative framework for understanding the empirical results from the survey.

Within the last decade, research has tried to describe the specificities of innovation in services (e.g. Gadrey et al. 1993, Sundbo 2001, Andersen et al. 2000, Gallouj 2002, Aa and Elfring 2002, Tidd and Hull 2005, Gallouj and Djellal 2010). Several empirical studies of innovation in services have been conducted (e.g. Gadrey et al. 1993, Brentani 1993, Finch et al. 1994, Sundbo 1996, 1998, Evangelista and Sirilli 1998, Gallouj 2000, Vermeulen 2001, Fuglsang 2002, Gallouj 2002, INNO-Studies 2004, Howells 2004, Hipp and Grupp 2005).

As a consequence of this work, an understanding of the special character of service innovation has emerged. Innovations in services are often small improvements integrated with daily work. The innovation process in services is generally very interactive involving many managers and employees. It involves employees bottom-up and strategy-making top-down (Sundbo 1996). The latter means that the firm strategy both is a guideline for and a control of the innovations. Service innovations are rarely R\&D based. By contrast, they are often market or customer based. Service innovations seem generally less technology-driven than manufacturing innovations (Sundbo 1996, Aa and Elfring 
2002). However, ICT is an exception that becomes increasingly important to service innovations (Evangelista and Sirilli 1998).

Innovation in experiences has not been investigated generally, only partially (for example innovation in tourism, Sundbo et al. 2007, Hjalager 2010). In our research we therefore asked the question: Does the description of service innovation as customer-driven, interactive and strategic apply to the experience sector, or are there further particularities of experience innovation that need to be examined?

\section{Method}

The web-based survey on which this report is based was carried out in Denmark in autumn 2007. A population of all firms in Danish experience industries with an e-mail address was contacted by e-mail and invited to answer the questionnaire on a web site. The survey population included 4500 firms ranging from 1 employee out of a total population of 14000 firms in the selected industries. The response rate was 29 thus 1315 firms are included in the population that is analysed. This response rate is not high, however, it is normal for surveys to firms and therefore may be thought satisfactory.

We have made an analysis of this selected population (the 1315 responding firms) in relation to the total population of 14000 firms to see if the selected population is representative. Tourist firms are under-represented while firms within design, image and branding are over-represented. Small firms with less than five employees are under-represented (50\% of the analyse-population while they are $68 \%$ of the total population). This must be kept in mind when the results are interpreted. This bias leads to a slight overestimation of innovation, since large experience firms are more often innovative than small ones. Besides this, the selected population is representative for the total population. On that 
basis we find that the results are sufficiently valid to be used for a general analysis of innovation tendencies in the Danish experience sector.

The results of the Danish survey about innovation tendencies in experience industries will be compared to the results of the European CIS surveys about innovation tendencies in services and industry (manufacturing) to get an assessment of whether the level of innovation in the experience sector is high or low. The CIS surveys, carried out by Eurostat and national agents (Eurostat 2004, Dansk center for forskningsanalyse 2004, 2006) provide representative results on innovation tendencies in industry and, for recent years, also services. In particular we will compare our results to the Danish CIS results to eliminate national variations, however, we will also compare them to European results.

\section{Innovation in the Danish experience sector compared to other sectors}

In all surveys, innovation has been measured in a simple way by asking if the firm has innovated within a two year period. We have in the experience sector asked about product and process innovations. We have compared our findings to the CIS results about these two forms of innovation. The results concern different time periods since the latest CIS results have not been published yet. Further, the CIS surveys distinguish between innovation activities and successful innovators. The latter are firms with production innovations that have been successfully launched on the market or process innovations that have been implemented. In our survey of experience firms, we have only asked about innovation activities. This makes comparison more complicated. However, the differences between firms with innovation activities and firms that are successful innovators are not large. For example, $44 \%$ of all firms in Europe have undertaken innovation activities in the period 1998-2000 while $41 \%$ were successful innovators (Eurostat 2004 p. 18). 
In table 1 we compare the type of innovation (product and process) between sectors. The results are not completely comparable because the CIS results concern successful innovators while we measure innovation activities, but we may assume that the differences are very small (cf. the statement above).

Table 1: Firms with innovation Percentages

\begin{tabular}{|c|c|c|c|c|c|c|c|}
\hline & $\begin{array}{l}\text { Our } \\
\text { survey } \\
\text { Den- } \\
\text { mark } \\
\text { Experi- } \\
\text { ence } \\
2004 \\
-2006\end{array}$ & $\begin{array}{l}\text { CIS3 } \\
\text { Europa } \\
\text { All firms } \\
1998 \\
-2000\end{array}$ & $\begin{array}{l}\text { CIS3 } \\
\text { Den- } \\
\text { mark } \\
\text { All firms } \\
1998 \\
-2000\end{array}$ & $\begin{array}{l}\text { CIS3 } \\
\text { Europe } \\
\text { Industry } \\
1998 \\
-2000\end{array}$ & $\begin{array}{l}\text { CIS3 } \\
\text { Den- } \\
\text { mark } \\
\text { Industry } \\
1998 \\
-2000\end{array}$ & $\begin{array}{l}\text { CIS3 } \\
\text { Europe } \\
\text { Services } \\
1998 \\
-2000\end{array}$ & $\begin{array}{l}\text { CIS3 } \\
\text { Den- } \\
\text { mark } \\
\text { Services } \\
1998 \\
-2000\end{array}$ \\
\hline $\begin{array}{l}\text { Firms that } \\
\text { have } \\
\text { innovation } \\
\text { activities }\end{array}$ & 69 & 44 & 44 & 47 & 52 & 40 & 37 \\
\hline $\begin{array}{l}\text { Succesful } \\
\text { innovators }\end{array}$ & n.a. & 41 & 42 & 44 & 49 & 36 & 34 \\
\hline $\begin{array}{l}\text { Only } \\
\text { product } \\
\text { innovation }\end{array}$ & 16 & 10 & 16 & 10 & 18 & 11 & 14 \\
\hline $\begin{array}{l}\text { Only } \\
\text { process } \\
\text { innovation }\end{array}$ & 9 & 7 & 5 & 8 & 6 & 5 & 5 \\
\hline $\begin{array}{l}\text { Product } \\
\text { and } \\
\text { process } \\
\text { innovation }\end{array}$ & 44 & 23 & 21 & 25 & 26 & 20 & 16 \\
\hline
\end{tabular}

According to this comparison, the experience sector is clearly more innovative than other sectors. In particular, experience firms combine product and process innovations more. As said, different time periods are compared thus one should be careful when making conclusions.

\section{Innovation in experience sub-sectors}

One hypothesis could be that a creative, and perhaps a particular 
entrepreneurial, spirit in the experience sector leads to more innovation. Another might be that the management of innovation and entrepreneurship in experience firms has not been very professional (dominated by artistic nonbusiness orientation) and is less oriented towards innovation (meaning: realisation of a business idea on the market) than in other sectors. These two hypotheses could be investigated by looking at different sub-sectors within the experience sector. Some sub-sectors are characterised by "exotic" managers and entrepreneurs - the creative artists and entrepreneurs - while other subsectors are not. In the latter sub-sectors a high innovation rate can only be explained by professional managerial competence.

We will therefore, in table 2, compare the innovation activity in different experience sub-sectors based on the results of our survey.

Table 2: Innovation in experience sub-sectors

Percentage of firms that had innovated 2004-2006. Denmark

\begin{tabular}{|l|c|}
\hline Sub-sector & $\begin{array}{l}\text { Have had } \\
\text { innovation } \\
\text { activities }\end{array}$ \\
\hline Tourism & 68 \\
\hline Art and culture & 73 \\
\hline $\begin{array}{l}\text { Entertainment and } \\
\text { leisure }\end{array}$ & 78 \\
\hline $\begin{array}{l}\text { Design, image and } \\
\text { branding } \\
\text { TOTAL }\end{array}$ & 59 \\
\hline
\end{tabular}

Own results

The different sub-sectors have different levels of innovation activities.

Entertainment and leisure (sport, amusement parks, museums, fair organisers and so forth) is the most innovative sub-sector and design, image and branding the least. This might seem a little surprising since entertainment and leisure might not traditionally have been considered the most creative sub-sector. However, this sector has probably been the most business oriented including 
large communication, movie and TV corporations. It has therefore probably been influenced by a more systematic industrial approach to innovation. More surprisingly is it that art and culture is number two in innovativeness. These results do not support the second hypotheses of artists and cultural institutions as absent-minded and not business-oriented, neither do they support the first hypothesis of creative people per se leads to innovation.

The least innovative sub-sector, design, image and branding might on the other hand traditionally have been considered the creative part of traditional industry. This result is therefore surprising. This result again supports a conclusion saying that creativity per se neither leads to innovation nor is a barrier to it. The conclusion is that innovation capability understood as realisation of a business idea on the market is another phenomenon than creativity. Innovation capability may be correlated with creativity, but it does not need to be so.

Tourism is placed in the middle, which reflects that this sector has traditionally been very little innovative, but innovations in this sector are increasing.

\section{Innovation characteristics}

In the quantitative research of innovation in services (e.g. SIC 1999, Djellal and Gallouj 2001, Drejer 2004, Eurostat 2004) a few characteristics of new products or processes have been much emphasized. These are characteristics that are special to service firms compared to industrial ones or are those that correlate most with the degree of innovation. When we now enter the experience sector, which in many respects is close to the services sector, it is natural to see if the same characteristics are central to understanding innovation in the experience sector. In this section we will emphasize a few of these main characteristics. We will further emphasize some characteristics that are supposed to be special to experiences. 


\section{Technology}

In contrast to industrial innovations, service innovations are rarely technological (Sundbo 1998, Gallouj 2002, INNO-Studies 2004). However, service innovations seem to increasingly becoming technological, particularly because of the increased use of ICT (Miozzo and Soete 2001, INNO-Studies 2004). Experience firms have also traditionally been characterised as being nontechnological (e.g. art and sport), but are increasingly becoming technological, particularly as ICT presents possibilities for providing experiences on the Internet, mobile phones etc. Are experience innovations more technological than service innovations? We can not answer that question but In table 3 we show the results of a question concerning how much technology means to the experience products. This gives an indication of how much technology means to innovation in experiences.

Table 3: Importance of technology for experience products Percentage

\begin{tabular}{|l|c|}
\hline ICT & \\
\hline Very much & 45 \\
\hline $\begin{array}{l}\text { To some } \\
\text { degree }\end{array}$ & 34 \\
\hline Not very much & 14 \\
\hline \begin{tabular}{l} 
Not at all \\
Other \\
technology \\
Very much \\
\hline $\begin{array}{l}\text { To some } \\
\text { degree } \\
\text { Not very much }\end{array}$
\end{tabular} & 6 \\
\hline \begin{tabular}{l} 
Not at all \\
\hline
\end{tabular} & 25 \\
\hline
\end{tabular}

Own results

Technology means quite a lot to experiences, particularly ICT, but also other 
technology. ICT has some or much importance to about $80 \%$ of the experience firms, and other technology has some or much importance to about $65 \%$. One may presume that this is reflected in the product and process innovations in experiences, which thus may be assumed to be rather technological or at least based on technology.

\section{Enterprise size}

The size of enterprises is the factor that most clearly correlates with innovation in services (SIC 1999). The CIS surveys also demonstrate a correlation between size and innovativeness in service and industry. In table 4 we have compared our results about innovation in the Danish experience sector with the CIS results about services and industry.

Table 4: Enterprise size and innovation Percentage of enterprises that have introduced product and/or process innovations

\begin{tabular}{|l|l|l|l|l|l|l|}
\hline $\begin{array}{l}\text { Size: } \\
\text { Number of } \\
\text { employees }\end{array}$ & $\begin{array}{l}\text { Our } \\
\text { survey } \\
\text { Denmark } \\
\text { Experience } \\
2004\end{array}$ & $\begin{array}{l}\text { Size: } \\
\text { Number of } \\
\text { employees }\end{array}$ & $\begin{array}{l}\text { CIS4 } \\
\text { Denmark } \\
\text { All firms } \\
2006\end{array}$ & $\begin{array}{l}\text { Size: } \\
\text { Number of } \\
\text { employees }\end{array}$ & $\begin{array}{l}\text { CIS3 } \\
\text { Europe } \\
\text { Industry } \\
1998\end{array}$ & $\begin{array}{l}\text { CIS3 } \\
\text { Europe } \\
\text { Services } \\
1998\end{array}$ \\
\hline $2-9$ & 66 & $2-2004$ & & -2000 \\
\hline $10-49$ & 73 & $10-49$ & 38 & & & \\
\hline $50+$ & 86 & $50-249$ & 47 & $10-49$ & 40 & 36 \\
\hline & & $250-999$ & 64 & $250+$ & 63 & 54 \\
\hline
\end{tabular}

* Only enterprises with 2 and more employees included

Eurostat 2004 figure 2.1.2, Dansk Center for Forskningsanalyse 2006 table $2 \mathrm{~b}$ and own results

The different surveys have slightly different size categories, however, the trends may be compared in table 4. For all sectors it is a clear that the larger the enterprise is, the more innovative it tends to be and experience firms are no exception. 


\section{Types of experiences}

In the discussion of experiences there has been a focus on the nature of experiences: Whether they are always entertaining or can also be educational (Pine and Gilmore 1999, Sundbo and Darmer 2008). Some experiences (e.g. rock festivals, Sundbo 2004) seem - although they have one obvious aim (e.g. music) - in reality to satisfy the social need to gather. This factor concerns the aim of new experience products - which needs in the customers they should satisfy. In the survey we asked about what characterises the experience products and in table 5 we present the results.

Table 5: Characteristics of experience products Percentage

\begin{tabular}{|l|c|c|c|}
\hline $\begin{array}{l}\text { How much do you agree in } \\
\text { the following statement: } \\
\text { Our experience products are: }\end{array}$ & Entertaining & Learning & $\begin{array}{l}\text { Improve } \\
\text { social } \\
\text { gathering }\end{array}$ \\
\hline Agree & 61 & 65 & 75 \\
\hline Neither agree, nor not agree & 18 & 16 & 12 \\
\hline Do not agree & 21 & 19 & 13 \\
\hline
\end{tabular}

Own results

The experience products are generally entertaining, learning and improve social gathering. The last factor seems to be the most important. This result suggests that experience products are complex and must satisfy several of the customers' needs. This multi-dimensionality of experiences must be taken into consideration when one innovates new products. The strong emphasis on the products' social tasks should particularly be kept in mind when firms develop new ICT-media based experiences such as computer games, TV-series and amusement products for mobile phones. 


\section{Conclusion}

Experience firms are very innovative. Their innovation rate is significantly above other sectors'. The innovations are more often new to the market. The experience sector is not only populated with creative and artistic people, the enterprises also have the ability to transform the creative ideas into business projects. This conclusion may be a little surprising since some assumptions have been that there are not many businessmen in the experience sector and those who are, are not very professional. This survey demonstrates the experience firms are fully able to innovate in terms of launching new products on the market or implementing process changes in the organisation.

The innovation rate varies between different experience industries. Entertainment and leisure has the highest innovation rate which may be explained as this sector always has been the most business oriented including large communication, movie and TV corporations. Design, image and branding is the least innovative sector. It might be interpreted as innovation capability understood as realisation of a business idea on the market is another phenomenon than creativity. Innovation capability may be correlated with creativity, but it does not need to be so.

The characteristics of the innovative experience innovations and innovative firms are similar to those found in services (and to a large degree in manufacturing). Not all innovations are technological, but an increasing number are becoming so. Large firms are more innovative than small ones. Innovation in experience firms thus is similar to innovation in services, which has been investigated, however, with some particularities that make it different. We have theoretically suggested several such ones. Empirically we have found that innovations in experiences are more IT-based than in other sectors.

Our attempt to create a survey of experience firms in Denmark demonstrates 
that it is possible to measure innovation in experiences with general measures that are also suitable for measuring innovation in the industry and service sectors. It can also be suggested that because experience production is not only a domain of the core experience firms analysed in this article, but is also becoming increasingly important in other sectors - service or industrial - who provide experiences as an addition to goods and services, some of the new issues dealt with in this article can also be of relevance for such sectors. 


\section{References}

Aa, W. van der and Elfring, T. (2002), Realizing innovation in services, Scandinavian Journal of Management, vol. 18, no. 2, pp. 155-71

Andersen, B., Howells, J., Hull, R., Miles, I. and Roberts, J. (eds.) (2000), Knowledge and Innovation in the Service Economy, Cheltenham (Elgar)

Brentani, U. (1993), The New Product Process in Financial Services: Strategy for Success, International Journal of Bank Marketing, vol. 11 no. 3 pp. 15-22

Caves, R. (2000), Creative Industries, Cambridge Mass. (Harvard University Press)

Dansk center for forskningsanalyse (Danish Centre of Research Analysis) (2004), Innovation i dansk erhvervsliv. Innovationsstatistik 2002. Tabelsamling (Innovation in Danish Business. Innovation statistics 2002. Tables), Århus (Dansk center for forskningsanalyse, Århus University)

Dansk center for forskningsanalyse (Danish Centre of Research Analysis) (2006), Dansk erhvervslivs innovation 2004. Tabelsamling (Innovation in Danish Business 2004. Tables), Århus (Dansk center for forskningsanalyse, Århus University)

Djellal, F. and Gallouj, F. (2001), Innovation in Services, Patterns of Innovation Organisation in Service Firms: Postal Survey Results and Theoretical Models, Science and Public Policy, vol. 28 no. 1 pp. 57-67

Drejer, I. (2004): Identifying innovation in survey of services: A Schumpeterian perspective, Research Policy, vol. 33 no. 3 pp. 551-62 
Erhvervs- og byggestyrelsen [Danish Enterprise and Construction Authority] (2008), Vækst via oplevelser [Growth via experiences], Copenhagen (Erhvervsog byggestyrelsen)

Eurostat (2004), Innovation in Europe. 2004 edition, Luxembourg (Eurostat) Evangelista, R and Sirilli, G. (1998), Innovation in the Servcie Sector: Results from the Italian Statistical Survey, Technological Forecasting and Social Change, vol. 58 no. 3 pp. 251-69

Finch, R, Fleck, J., Procter, R., Scarbrough, H., Tierney, M. and Williams, R. (1994), Expertise and Innovation, Oxford (Clarendon)

Fuglsang, L. (2002), Systems of Innovation in Social Services, in: Sundbo, J. and Fuglsang, L., Innovation as Strategic Reflexivity, London (Routledge)

Gadrey, J., Gallouj, F., Lhuillery, S., Weinstein, O. and Ribault, T. (1993), Etude effectuée pour le ministère de l'enseignement superieure et de la recherche, Lille (IFRESI-CNRS)

Gallouj, F. (2000), Economie de l'innovation dans les services, Paris (Harmattan)

Gallouj, F. (2002), Innovation in the Service Economy, Cheltenham (Elgar)

Gallouj, F. and Djellal, F. (eds.) (2010), The Handbook of Innovation and Services, Cheltenham (Elgar)

Hipp, C. and Grupp, H. (2005), Innovation in the Service Sector, Research Policy, vol. 34 no. 4 pp. 517-35 
Hjalager, A. (2010), A Review of Innovation Research in Tourism, Tourism Management, vol. 31 no. 1 pp. 1-12

Howells, J, (2004): Innovation, Consumption and Services: Encapsulation and the Combinatorial Role of Services, The Service Industries Journal, vol. 24, no. 1 , pp. $19-36$

INNO-Studies (2004), Innovation in Servcies: Issues at Stake and Trends, INNO-Studies 2001: Lot 3 (ENTR-C/2001), Bruxelles (the EU Commisssion)

Miozzo, M. and Soete, L. (2001): Internationalization of Services. A Technological Perspective, Technological Forecasting and Social Change, vol. 67 no. 7 pp. $159-85$.

Pine, J.B. and Gilmore, J.H. (1999), The Experience Economy, Boston (Harvard Business School)

SIC (Service development, Internationalisation and Competence development) (1999), Danish Service Firms' Innovation Activities and Use of ICT, Based on a Survey, Report no. 2, Roskilde (Centre of Service Studies, Roskilde University)

Sundbo, J. (1996), Balancing Empowerment, Technovation, vol. 16 no. 8 pp. 397-409

Sundbo, J. (1998), The Organisation of Innovation in Services, Copenhagen (Roskilde University Press)

Sundbo, J. (2001), The Strategic Management of Innovation, Cheltenham (Elgar)

Sundbo, J. (2004) The management of rock festivals as the basis for business 
development: an example of the growing experience economy, International Journal of Entrepreneurship and Innovation Management vol. 4 no. 6 pp. 587612

Sundbo, J. (2009), Innovation in the experience economy. A taxonomy of innovation organisations, The Service Industries Journal vol. 29 no. 4 p. 43155.

Sundbo, J. and Darmer, P. (eds.) (2008), Creation of Experience in the Experience Economy, Cheltenham (Elgar)

Sundbo, J., Orfila-Sintes, F. and Sørensen, F. (2007), The Innovative Behaviour of Tourism Firms - comparative studies of Denmark and Spain, Research Policy, vol. 36 no. 1 pp. 88-106.

Tidd, J. and Hull, F. (2005), Service Innovation, London (World Scientific Publishing)

Vermeulen, P. (2001), Organizing Product Innovation in Financial Services, Nijmegen (Nijmegen University Press) 
Appendix A The experience sector and sub-sectors

Experience industries included in the survey:

Tourism

Hotels

Conference centres

Youth Hostels

Camping sites

Other facilities for leisure

Restaurants

Cafeterias, grill bars etc.

Banqueting rooms

Pubs

Discoteques and night clubs

Cafes

Catering

River transport

Land passenger transport

Tourist information

Travel agencies

Tourist guide enterprises

Holiday residence renting bureaus

Marinas

Arts and culture

Publishing companies

Book editors

Publisher of discs and CDs

Publishers of other kind

Gold and silver smiths

Producers of music instruments

Picture and video production

Picture and video wholesale

Cinemas

TV companies

Radio companies

Theatres and concert organisers

Independent artists

Culture houses

Entertainment and leisure

Producers of sport equipment

Producers of toy and games

Fair organisers

Amusement parks 
Other amusement enterprises

Museums

Botanical and zoological gardens

Sport and swimming-pool installations

Other sport installations (stadiums etc.)

Sport clubs

Other sport activities

Lotteries

Beauty salons

Sun, motion and health care centres

Other leisure activities

Design, image and branding

Development of software

Architects

PR and advertising agencies

Photographers

Industrial design 